\title{
Prevalence of Opportunistic Intestinal Parasites and Associated Factors among HIV Patients while Receiving ART at Arba Minch Hospital in Southern Ethiopia: A Cross-sectional Study
}

\author{
Getaneh Alemu $^{1 *}$, Dagninet Alelign ${ }^{1}$, Ashenafi Abossie ${ }^{1}$
}

\section{OPEN ACCESS}

Citation: Getaneh Alemu, Dagninet Alelign, Ashenafi Abossie. Prevalence of Opportunistic Intestinal Parasites and Associated Factors among HIV Patients while Receiving ART at Arba Minch Hospital in South Ethiopia: A Crosssectional Study. Ethiop J Health Sci.2018;28(2):147.

doi:http://dx.doi.org/10.4314/ejhs.v28i2.6

Received: September 5, 2017

Accepted: October 6, 2017

Published: March 1, 2018

Copyright: (C) 2018 Getaneh Alemu, et al . This is an open access article distributed under the terms of the Creative Commons Attribution License, which permits unrestricted use, distribution, and reproduction in any medium, provided the original author and source are credited. Funding: Nil

Competing Interests: The authors declare that this manuscript was approved by all authors in its form and that no competing interest exists.

Affiliation and Correspondence:

${ }^{1}$ Department of Medical Laboratory

Science, Arba Minch University, Arba Minch,Ethiopia

*Email: getanehmlt@gmail.com

\section{ABSTRACT}

BACKGROUND: Opportunistic Intestinal Parasites (OIPs) commonly cause morbidity in HIV/AIDS patients due to the decline of $\mathrm{CD}^{+} \mathrm{T}$-cells. The burden of Opportunistic Intestinal Parasitic Infections (OIPIs) in Ethiopia is expected to be high due to poor sanitation and co-pandemicity of HIV/AIDs. Therefore, frequent assessment of the magnitude and associated factors for intestinal parasitosis is essential for the management of HIV/AIDS patients.

METHODS: A hospital based cross-sectional study was conducted among patients attending Arba Minch Hospital Antiretroviral Therapy (ART) Clinic from March to June 2016. Stool specimens were processed for parasitological examination using direct wet mount, formol-ether sedimentation and modified Ziehl-Neelsen staining techniques. CD4+ T-cell count data were taken from patients' medical records. A structured questionnaire was used to collect data on socio-demographic characteristics and possible associated factors for OIPIs. All the data were analyzed using SPSS version 20.

RESULTS: Two hundred and twenty ART patients participated in the study. The overall prevalence of intestinal parasitic infections was $28.18 \%$ while that of OIPIs alone was $17.72 \%$. Among identified intestinal parasites, Cryptosporidium species accounts for the highest frequency (19/220, 8.63\%), followed by Cyclospora species (13/220, 5.90\%). Presence of domestic animals $(A O R=2.07$, 95\%CI:1.07-8.40, $P=0.032$ ) and CD4+ T-cell count $<500$ cell $/ \mu l$ $(A O R=4.66,95 \% C I: 1.17-5.35, \quad P=0.001)$ were significantly associated with OIPIs.

CONCLUSION: The study indicated that co-infection rate of OIPs is high among ART patients. It also found that contact with domestic animals and having CD4+ count $<500 \mathrm{cell} / \mu \mathrm{l}$ predict for the presence of OIPs.

KEYWORDS: Opportunistic intestinal parasites, ART patients, CD4 status 


\section{INTRODUCTION}

Human Immuno Deficiency Virus (HIV) infection is a major public health problem. Its emergence and pandemic spread currently poses the greatest challenge to the globe. According to the World Health Organization (WHO) report, there were 2.1 million new HIV infections worldwide and a total of 36.7 million people were living with the virus in 2015. Eastern and Southern Africa, where Ethiopia is located, is one of the most affected regions where there were 19 million cases in 2015 (1).

The hallmark of HIV infection is depletion of CD4+ $\mathrm{T}$ lymphocytes resulting in overall impairment of the immune response $(2,3)$. Therefore, HIV/AIDS patients are more likely to acquire other infections. They are prone to more severe morbidiry once the infection is established. They also have disseminated rather than localized infection. Moreover, they are unable to effectively clear infecting micro-organisms. All these lead to greater morbidity and mortality, mainly because of opportunistic infections (4). Opportunistic infections can be of viral, bacterial, fungal or parasitic origins which usually affect the gastrointestinal, nervous and respiratory systems $(5,6)$. About $80 \%$ of deaths of AIDS patients are related to opportunistic infections rather than the virus itself, and of these, more than $47 \%$ happen due to OIPs (7).

Opportunistic protozoan parasites such as Cryptosporidium species (spp), Cyclospora cayetanensis, Isospora belli and Microsporidia spp have been identified in individuals living with HIV/AIDS $(8,9)$. OIPIs have been a major source of morbidity in tropical countries where HIV/AIDS is endemic (10). S.stercoralis causes a severe human parasitic infection primarily because of its potential for serious and even lethal diseases in immunosuppressed patients (11). The sign and symptoms include severe chronic watery diarrhea with frequent and explosive bowel movements accompanied by loss of appetite, weight loss, abdominal cramp, nausea, fever, headache and vomiting $(12,13)$. However, the intensity of the harm depends on parasite species, nature and course of infection, nature of interactions between the parasite and concurrent infections, nutritional and immunological status of the host and numerous socioeconomic factors $(7,14)$.

Although there has been an improvement with the introduction of ART for individuals in HIV/AIDS, the presence of OIPIs create serious challenge in reducing associated morbidity and mortality. Studies have also evidenced that the prevalence of OIPs among those patients is high (15). Nevertheless, with the introduction of combination antiretroviral therapy and also more effective prophylaxis against these 'classic' opportunistic infections, the rate has decreased. However, OIPIs still represent a frequent cause of morbidity and mortality in most developing countries $(16,17)$.

In Ethiopia, OIPIs among HIV patients are estimated to be high due to poor level of environmental sanitation and personal hygiene plus contamination of food and drinking water. This happens because of improper disposal of human and animal excreta. Patients are not also frequently been screened for these pathogens on regular follow-up at monitoring centers/clinics (18). Hence, informationa bout the co-infection rate of OIPs among patients attending ART is very limited. In this regard, the present study was initiated to assess the magnitude of OIPIs and associated factors among ART following patients at Arba Minch Hospital, Southern Ethiopia.

\section{MATERIALS AND METHODS}

Study design and area: A hospital based crosssectional study was conducted in Arba Minch Hospital ART Clinic from March to May, 2016. Arba Minch is located in the southern part of the country about $454 \mathrm{~km}$ far from Addis Ababa, the capital of Ethiopia. Its population is around 70,000 (19). Arba Minch Hospital is serving a population of more than 1.5 million. It provides different health services such as outpatients, inpatients, pharmacy and laboratory with full service, especially for ART purpose. The hospital has been providing counseling and testing service for HIV since the early 1990 s. It also serves as a referral center for all other health institutions in Gamo Gofa Zone. Screening as well as treatment and follow-up of HIV/AIDS patients is one of the routine services provided in the hospital.

DOI: http://dx.doi.org/10.4314/ejhs.v28i2.6 
Sample size and sampling technique: The study participants consist of randomly selected ART following patients who came to Arba Minch Hospital ART Clinic during the data collection period. Sample size was calculated using single population proportion formula with the following assumptions: margin of error $=5 \%$ at $95 \%$ confidence level, $\mathrm{p}=0.1538$ from similar study conducted in Jimma (20). Hence, the total sample size was 230 after adding $15 \%$ for nonrespondents. Systematic random selection method was followed by calculating $\mathrm{k}$ value (interval), where $\mathrm{N}=1600, \mathrm{n}=230$ and $\mathrm{K}=1600 / 230=7$. The first subject was recruited by lottery method and then every $7^{\text {th }}$ ART following patient was included in the study. Those ART attending patients whose age was $\geq 12$ years old who were willing to participate in the study were included while severely ill patients who were unable to respond to questions and those $<12$ years of age were excluded.

Data collection: A pre-tested structured questionnaire administered through face-to-face interview was used to collect data regarding sociodemographic characteristics and associated factors for OIPIs among patients. CD4+ count and ART status were taken from patients' medical records . which was done during the enrollment of patients in the study period. For the purpose of parasitological examination, each study participant was informed about sample collection and supplied with labeled plastic stool cup, toilet paper and applicator stick and instructed to collect around 3-5 grams of stool. Direct saline wet mount smear was examined immediately to detect the presence of motile parasite stages while the rest of the sample was preserved with $10 \%$ formalin. About 1 gram from the preserved stool was concentrated and examined by the formolether concentration techniques for the detection of ova, cyst and larvae of different intestinal parasites following standard procedure as described elsewhere (21), and modified ziehl-Neelsen technique was followed to detect oocysts of Cryptosporidium spp, Isospora belli, and Cyclospora spp (22). The direct wet mount and formol-ether concentrated preparations were examined under 10x and 40x objectives while the modified ziehl-Neelsen stained slides were inspected under $100 \mathrm{x}$ objectives.

Quality control: All laboratory materials and reagents were checked for expiry and stored appropriately by experienced laboratory professionals. Standard operating procedures were strictly followed for stool examination. Specimens were also checked for serial number, quality and procedures of collection. To minimize missed parasite identification and discrepancy, each slide was examined by the two trained professionals. In addition, intestinal coccidian parasite identifications were checked using colored atlas.

Statistical analysis: Data was entered and analyzed using SPSS version 20.0. Descriptive statistics were calculated to describe the the characteristics of the study population. Bivariate logistic regression was used to assess associations between dependent and independent variables. Multivariate regression analysis was then applied for variables with $\mathrm{p} \leq 0.25$ in the bivariate analysis. Association between variables was considered statistically significant only if $\mathrm{P}$-value $\leq 0.05$ at 95\% confidence level.

Ethics: Ethical approval for the research was granted by the Review Board of Arba Minch University. Official permission letter was also obtained from Arba Minch Hospital. All the study participants were informed about the purpose of the study and their right to refuse or accept. Written informed consent/assent was obtained prior to the interview. All results of infected ART patients were reported to healthcare providers with their codes so that they could get prompt treatment.

\section{RESULTS}

Socio-demographic characteristics of the study participants: A total of 220 patients $(91$ males and 129 females) participated in the study with a response rate of $95.65 \%$. Ten patients were excluded due to extremely outlier CD4+ results and incompleteness of records and inablility to bring stool sample. About 56.36\%(124/220) and $43.64 \%(96 / 220)$ were urban and rural dwellers respectively. The majority (76.82\%) were aged in between 26-49 (Table 1).

DOI: http://dx.doi.org/10.4314/ejhs.v28i2.6 
Table 1: Socio-demographic, economic and clinical characteristics of patients attending Arba Minch Hospital ART Clinic from March to May, 2016 (N=220).

\begin{tabular}{|c|c|c|c|}
\hline \multicolumn{2}{|l|}{ Variables } & \multicolumn{2}{|c|}{ Number $(\%)$} \\
\hline \multirow[t]{2}{*}{ Sex } & Males & 91 & $(41.36)$ \\
\hline & Females & 129 & $(58.64)$ \\
\hline \multirow[t]{4}{*}{ Age group } & $12-25$ & 31 & (14.09) \\
\hline & $26-49$ & 169 & $(76.82)$ \\
\hline & $>50$ & 20 & $(9.09)$ \\
\hline & Unable to read \& write & 48 & $(21.82)$ \\
\hline \multirow[t]{2}{*}{ Educational status } & Primary/secondary & 120 & $(54.55)$ \\
\hline & Diploma \& above & 52 & $(23.63)$ \\
\hline \multirow[t]{3}{*}{ Residence } & Rural & 96 & $(43.64)$ \\
\hline & Urban & 124 & $(56.36)$ \\
\hline & Married & 148 & $(67.27)$ \\
\hline \multirow[t]{2}{*}{ Marital status } & Unmarried & 45 & $(20.45)$ \\
\hline & Divorced/widowed & 27 & $(12.28)$ \\
\hline \multirow[t]{2}{*}{ Use latrine } & Yes & 189 & $(85.90)$ \\
\hline & No & 31 & $(14.10)$ \\
\hline \multirow[t]{3}{*}{ Monthly income } & $>2000$ birr & 30 & $(13.63)$ \\
\hline & $1000-2000$ & 109 & $(49.55)$ \\
\hline & $<1000$ birr & 81 & $(36.82)$ \\
\hline \multirow[t]{2}{*}{ Common food source } & Cooked at home & 184 & (83.64) \\
\hline & From hotel & 36 & $(16.36)$ \\
\hline \multirow[t]{2}{*}{ Habit of washing fruits/vegetable } & Yes & 186 & $(84.55)$ \\
\hline & No & 34 & $(15.45)$ \\
\hline \multirow[t]{2}{*}{ Swimming habit } & Yes & 53 & $(24.09)$ \\
\hline & No & 167 & $(75.91)$ \\
\hline \multirow[t]{2}{*}{ Habit of eating raw meat } & Often or always & 183 & $(83.18)$ \\
\hline & Never or occasionally & 37 & $(16.82)$ \\
\hline \multirow[t]{2}{*}{ Hand washing habit before meal } & Often or always & 211 & $(95.91)$ \\
\hline & Never or occasionally & 9 & $(4.09)$ \\
\hline \multirow[t]{2}{*}{ Hand washing habit after defecation } & Often or always & 198 & $(90.0)$ \\
\hline & Never or occasionally & 22 & $(10.0)$ \\
\hline \multirow[t]{2}{*}{ Water source for drinking } & Pipe water & 206 & (93.64) \\
\hline & River/stream/lake & 14 & $(6.36)$ \\
\hline \multirow[t]{2}{*}{ Domestic animals in the compound } & Yes & 98 & $(44.55)$ \\
\hline & No & 122 & $(55.45)$ \\
\hline \multirow[t]{2}{*}{ History of diarrheal in $<3$ months } & Yes & 21 & $(9.55)$ \\
\hline & No & 199 & $(90.45)$ \\
\hline \multirow[t]{3}{*}{ ART starting time } & $>5$ years ago & 48 & $(21.82)$ \\
\hline & $2-5$ years ago & 101 & $(45.91)$ \\
\hline & $<2$ years ago & 71 & $(32.27)$ \\
\hline \multirow[t]{3}{*}{ CD4 status } & $>500 \mathrm{cell} / \mu \mathrm{l}$ & 79 & (35.91) \\
\hline & $200-500 \mathrm{cell} / \mu \mathrm{l}$ & 98 & $(44.55)$ \\
\hline & $<200 \mathrm{cell} / \mu \mathrm{l}$ & 43 & (19.54) \\
\hline
\end{tabular}

Prevalence of intestinal parasites: Among the total of 220 study participants, intestinal parasites were detected in $62(28.18 \%)$ patients while the remaining $158(71.81 \%)$ were negative. Infection

DOI: http://dx.doi.org/10.4314/ejhs.v28i2.6 
by OIPs accounted for $17.72 \%(39 / 220)$. Ten types of intestinal parasites were identified, and Cryptosporidium spp were the most frequent parasites detected $(19,8.63 \%)$ followed by Cyclospora spp (13,5.9\%). Among nonopportunistic intestinal parasites, E. histolytica was with the highest prevalence (3.62\%) followed by $S$. stercoralis, G. lamblia and A. lumbricoides $(1.81 \%$ each), Taenia spp (1.36\%) and Hookworm and H. nana (0.91\% each) (Table 2).

Table 2: Prevalence of intestinal parasites among patients attending Arba Minch Hospital ART Clinic from March to May, $2016(\mathrm{~N}=220)$.

\begin{tabular}{lll}
\hline Type of para & Frequency & $\%$ \\
\hline Cryptosporidium spp & 19 & $(8.63)$ \\
Cyclosporaspp & 13 & $(5.90)$ \\
Isospora belli & 3 & $(1.36)$ \\
S. stercoralis & 4 & $(1.81)$ \\
E. histolytica/dispar & 8 & $(3.62)$ \\
A.lumbricoides & 4 & $(1.81)$ \\
G. lamblia & 4 & $(1.81)$ \\
Taeniaspp & 3 & $(1.36)$ \\
Hook worm & 2 & $(0.91)$ \\
H. nana & 2 & $(0.91)$ \\
\hline
\end{tabular}

Factors associated with opportunistic intestinal parasites: The present study shows that females $(11.3 \%)$ were more affected by OIPs than males (6.3\%). However, the difference was not statistically significant $(\mathrm{AOR}=0.53,95 \% \mathrm{CI}$ : 0.03 $2.65, \mathrm{p}=0.269$ ). High rate of OIPIs was observed in the age group of $26-49$ years $(76.81 \%)$; but the difference was not significant $(\mathrm{AOR}=2.44,95 \%$ CI: $0.92-6.03, p=0.263)$. In multivariate logistic regression analysis, patients who had contact with domestic animals in their compound were more likely to acquire OIPIs than patients who had no contact with domestic animals $(\mathrm{AOR}=2.07$, 95\%CI: $1.07-8.40, \mathrm{P}=0.032$ ). Patients who stayed $<2$ years duration on ART had more chance to be infected with OIPs than patients who took ART for $>2$ years $(\mathrm{AOR}=1.27,95 \% \mathrm{CI}: 1.71-3.57, \mathrm{P}=$ 0.041). Moreover, patients whose CD4 T-cell count was $<500$ cell $/ \mu$ l were more likely to be infected by an OIPs (AOR=4.66, 95\% CI:1.175.35, $\mathrm{P}=0.001$ ) (Table 3).

Among OIPs, Cryptosporidium spp had the highest prevalence $(8.63 \%)$, followed by
Cyclospora spp (5.9\%). Cryptosporidium spp infection was higher among patients who had CD4+ T - cell count $<200$ cells/ $\mu$ l than patients who had a CD4+ T-cell count above 500 cells $/ \mu 1$ $\left(\mathrm{x}^{2} ; 9.34, \mathrm{p}=0.001\right)($ Table 4$)$.

\section{DISCUSSION}

In this study on HIV positive patients who were taking antiretroviral treatment, the prevalence of intestinal parasites was $28.18 \%$. It is similar with the result of a study conducted in India $(28.2 \%)$ (23). The overall intestinal parasite prevalence was lower than previous studies reported from Jimma (62\%) (20) and Thailand (50\%) (24).

Among opportunistic intestinal parasites, Cryptosporidium spp was the most prevalent and known causative agent for the majority of enteritis and diarrhea. Its prevalence was higher ,19(8.63\%), than findings from Burkina Faso $(5.2 \%)$ (26). However, it was inconsistent with a similar study from India $(28.7 \%)$ (23). This difference might be due to variations in sample size, diagnostic approaches followed and treatment to prevent OIPs in ART patients. The second most prevalent opportunistic intestinal parasite was Cyclospora spp (5.9\%) which goes in line with a similar study conducted in Thailand $(5 \%)(24)$. However, it is lower than the findings from Jimma (10\%) and Northern India (31\%) $(20,23)$. The prevalence of I.belli infection observed in this study was low $(1.36 \%)$ as compared to findings from Tanzania (11.6\%), Zaire (2.4\%) and Gondar (2.4\%) (25-27). However, it was consistent with reports from Addis Ababa (1.4\%) (28). 
Table 3: Bivariate and multivariable logistic regression analysis of opportunistic intestinal parasitic infection with associated factors among ART following patients in Arba Minch Hospital, $2016(\mathrm{~N}=220)$.

\begin{tabular}{|c|c|c|c|c|c|c|c|}
\hline Risk factors & Category & $\begin{array}{l}\text { Number } \\
\text { examined }\end{array}$ & $\begin{array}{l}\text { Rate of OIP } \\
\text { Infection N(\%) }\end{array}$ & $\begin{array}{l}\text { Crude } \\
\text { OR (95\% CI) }\end{array}$ & $P$ value & $\begin{array}{l}\text { Adjusted } \\
\text { OR* (95\% CI) }\end{array}$ & $P$ value \\
\hline \multirow[t]{2}{*}{ Sex } & Males & 91 & $14(15.38 \%)$ & 1.00 & & & \\
\hline & Females & 129 & $25(19.38 \%)$ & $1.06[0.87-1.37]$ & 0.220 & $0.53[0.03-2.65]$ & 0.269 \\
\hline \multirow[t]{4}{*}{ Age group } & $12-25$ & 31 & $13(41.93 \%)$ & $1.53[0.87-1.99]$ & 0.351 & & \\
\hline & $26-49$ & 169 & $19(11.24 \%)$ & $2.44[0.92-6.03]$ & 0.263 & & \\
\hline & $>50$ & 20 & $7(35.0 \%)$ & 1.00 & & & \\
\hline & Unable to read \& write & 48 & $13(27.08 \%)$ & $0.32[0.04-4.3]$ & 0.410 & & \\
\hline \multirow{2}{*}{ Educational status } & Primary/secondary & 120 & $20(16.67 \%)$ & $0.55[0.94-4.6] 1.00$ & 0.540 & & \\
\hline & Diploma \& above & 52 & $6(11.53 \%)$ & & & & \\
\hline \multirow{3}{*}{ Residence } & Rural & 96 & $16(16.67 \%)$ & $0.99[0.49-2.01]$ & 0.300 & & \\
\hline & Urban & 124 & $23(18.55 \%)$ & 1.00 & & & \\
\hline & Married & 148 & $26(17.57 \%)$ & $0.61[0.14-1.58]$ & 0.260 & & \\
\hline \multirow{2}{*}{ Marital status } & Unmarried & 45 & $8(17.78 \%)$ & $0.47[0.21-1.46] 1.00$ & 0.280 & & \\
\hline & Divorced/widowed & 27 & $5(18.52 \%)$ & & & & \\
\hline \multirow[t]{2}{*}{ Use latrine } & Yes & 189 & $28(14.81 \%)$ & & & & \\
\hline & No & 31 & $11(35.45 \%)$ & $0.63(0.26-1.48)$ & 0.125 & $0.8(0.6-7.11)$ & 0.174 \\
\hline \multirow[t]{3}{*}{ Monthly income } & $>2000$ birr & 30 & $1(3.33 \%)$ & 1.00 & & & \\
\hline & $1000-2000$ & 109 & $17(15.60 \%)$ & $0.96[0.92-3.54]$ & 0.061 & $0.82[0.52-3.82]$ & 0.075 \\
\hline & $<1000$ birr & 81 & $21(25.92 \%)$ & $1.28[0.01-4.11]$ & 0.097 & $0.64[0.12-2.38]$ & 0.421 \\
\hline \multirow[t]{2}{*}{ Common food source } & Cooked at home & 184 & $37(20.11 \%)$ & $1.27[0.41-3.92] 1.00$ & 0.073 & $0.93[0.54-2.36]$ & 0.673 \\
\hline & From hotel & 36 & $2(5.56 \%)$ & & & & \\
\hline Habit of washing & Yes & 186 & $36(19.35 \%)$ & $2.35[1.03-4.37] 1.00$ & 0.445 & & \\
\hline fruits/vegetable & No & 34 & $3(8.82 \%)$ & & & & \\
\hline \multirow[t]{2}{*}{ Swimming habit } & Yes & 53 & $13(24.53 \%)$ & $0.64[0.94-4.01]$ & 0.058 & $0.36[0.12-2.38]$ & 0.491 \\
\hline & No & 167 & $26(15.57 \%)$ & 1.00 & & & \\
\hline \multirow{2}{*}{$\begin{array}{l}\text { Habit of eating raw } \\
\text { meat }\end{array}$} & Often or always & 183 & $30(16.39 \%)$ & 1.00 & & & \\
\hline & Never or occasionally & 37 & $9(24.32 \%)$ & $0.99(0.43-2.27)$ & 0.989 & & \\
\hline
\end{tabular}

DOI: http://dx.doi.org/10.4314/ejhs.v28i2.6 


\begin{tabular}{|c|c|c|c|c|c|c|c|}
\hline Hand washing habit & Often or always & 211 & $35(16.59 \%)$ & 1.00 & & & \\
\hline before meal & Never or occasionally & 9 & $4(44.44 \%)$ & $0.38(0.09-1.49)$ & 0.167 & $0.76(0.09-6.71)$ & 0.460 \\
\hline Hand washing habit & Often or always & 198 & $27(13.63 \%)$ & 1.00 & & & \\
\hline after defecation & Never or occasionally & 22 & $12(54.54 \%)$ & $0.62(0.06-7.15)$ & 0.719 & & \\
\hline Water source for & Pipe water & 206 & $34(16.50 \%)$ & 1.00 & & & \\
\hline drinking & River/stream/lake & 14 & $5(35.71 \%)$ & $0.43(0.13-1.42)$ & 0.388 & & \\
\hline Domestic animals in & Yes & 98 & $24(24.49 \%)$ & $2.17[1.05-5.46]$ & 0.023 & $2.07[1.07-8.40]$ & 0.032 \\
\hline the compound & No & 122 & $15(12.30 \%)$ & 1.00 & & & \\
\hline Diarrheal history in & Yes & 21 & $16(76.19 \%)$ & $2.14[0.76-5.32]$ & 0.089 & $0.03[0.63-2.82]$ & 0.073 \\
\hline $\begin{array}{l}<3 \text { months } \\
\text { ART starting time }\end{array}$ & $\begin{array}{l}\text { No } \\
>5 \text { years ago }\end{array}$ & $\begin{array}{l}199 \\
48\end{array}$ & $\begin{array}{l}23(1156 \%) \\
9(18.75 \%)\end{array}$ & $\begin{array}{l}100 \\
1.00\end{array}$ & & & \\
\hline & $2-5$ years ago & 101 & $12(11.88 \%)$ & $1.38[0.52-3.61]$ & 0.031 & $2.079[0.71-6.01]$ & 0.058 \\
\hline & $<2$ years ago & 71 & $18(25.35 \%)$ & $2.29[2.93-5.65]$ & 0.002 & $1.27[1.71-3.57]$ & 0.041 \\
\hline CD4 status & $\geq 500 \mathrm{cell} / \mu \mathrm{l}$ & 79 & $5(6.33 \%)$ & 1.00 & & & \\
\hline & $<500 \mathrm{cell} / \mu 1$ & 141 & $34(24.11 \%)$ & $7.99[3.04-18.01]$ & 0.000 & $4.66[1.17-5.35]$ & 0.001 \\
\hline
\end{tabular}

*adjusted ratio only computed for $\mathrm{p} \leq 0.25$ in the bivariate analysis

Table 4: Association of Opportunistic intestinal parasites with CD4+ T-cell count status of ART patients attending Arba Minch Hospital ART Clinic from March to May, $2016(\mathrm{~N}=220)$.

\begin{tabular}{|c|c|c|c|c|c|}
\hline Types of Parasites Prevalence & $\begin{array}{c}\text { CD4+ } \\
>500 \text { cells } / \mu 1 \\
(\mathrm{~N}=79) \\
\end{array}$ & $\begin{array}{c}\text { CD4+ } \\
500-200 \text { cells } / \mu 1 \\
(\mathrm{~N}=98)\end{array}$ & $\begin{array}{c}\text { CD4+ } \\
<200 \text { cells/ } \mu 1 \\
(\mathrm{~N}=43) \\
\end{array}$ & $x^{2}$ & p-value \\
\hline Cryptosporidium spp & 2 & 8 & 9 & 9.34 & 0.001 \\
\hline Cyclosporaspp & 3 & 5 & 5 & 2.95 & 0.024 \\
\hline I. belli & 0 & 2 & 1 & & \\
\hline S. stercoralis & 0 & 3 & 1 & & \\
\hline Total & 5 & $18(8.18 \%)$ & $16(7.27 \%)$ & & \\
\hline
\end{tabular}

DOI: http://dx.doi.org/10.4314/ejhs.v28i2.6 
S. stercoralis was less frequently detected (1.8\%). It is one of the most difficult intestinal parasites to diagnose because conventional stool examination has low sensitivity even when examined several times. This is because the parasite load is low in the majority of infected individuals, and the larval output is minimum and irregular (29). The difference observed in infection rate between the present study and earlier reports (13.6\%) might be due to the difference in the diagnostic methods used (30).

Based on this finding, the prevalences of Cryptosporidium and cyclospora spps were higher among opportunistic intestinal parasites and the prevalence of G. lamblia and E.histolytica were higher among non-opportunistic parasites. This is in line with findings from Jimma and India $(20,23)$. In this study, the prevalence of OIPs has a clear statistically significant association with the presence of domestic animal, CD4 status, ART status and stool consistency.

Consistent with a previous study (31), patients who had contact with domestic animals had more chance to acquire OIPIs. Cryptosporidium and Cyclosporas spp were significantly $(\mathrm{P}<0.05)$ associated with the presence of domestic animals in their compounds. The prevalence of both species was lower than other studies in Ethiopia (17). In agreement with other studies in Ethiopia (32), a lower rate of cryptosporidiosis observed in this study might be due to ART treatment as it elicits immunological responses (33).

Contact with domestic animals $(\mathrm{P}=0.001)$ and $\mathrm{CD} 4+$ count $<200$ cell $/ \mu 1(\mathrm{P}=0.001)$ were also found to be significantly associated with the presence of Cryptosporidium spp infection. Consistent with another study, cryptosporidiosis occurs in AIDS patients when the CD4+ T- cell count is $<200$ cells/ $\mu \mathrm{l}(34)$. Cyclospora spp was significantly associated with a history of diarrhea $<3$ months $(\mathrm{P}=0.031)$ and $\mathrm{CD} 4$ status < 200cells $/ \mu 1 \quad(\mathrm{P}=0.04)$. Similarly, this result also showed a higher prevalence of these OIPIs related to CD4+ T-cells counts of $<200$ cells/ $\mu 1(35)$.
Many researchers have used CD4+ T - cell count as the marker for monitoring disease progress and initiating therapy in HIV patients (36). Our results show that patients whose CD4+ T-cell count $<$ $200 / \mu \mathrm{L}$ had an association with OIPIs $(\mathrm{AOR}=4.66, \quad 95 \% \mathrm{CI}: 1.17-5.35, \quad \mathrm{P}=0.001)$ compared to patients who had CD4+ T-cell count $>500 / \mu \mathrm{l}$. Several other studies have corroborated that CD4+ $\mathrm{T}$ cell count is lower among co-infected patients as compared to HIValone infected ones, and severe immune suppression is seen in those with CD4+ $\mathrm{T}$ cell count $<200$ cells $/ \mu 1(20,23,25)$.

Some parasites were not detected because of the non-availability of reagents and the nonapplicability of all techniques, such as the waterether sedimentation method for Microsporidia and molecular methods to differentiate some species of the parasites. Therefore, the prevalence of intestinal parasites among the study participants might have been underestimated. In conclusion, the results of the present study indicated that the prevalence of OIPIs is high among ART patients. This study also found that contact with domestic animals and a CD4+ count $<500$ cell $/ \mu \mathrm{l}$ are predicting factors for the presence of OIPs. Therefore, regular screening, monitoring and appropriate treatment should be given to prevent OIPIs among all HIV/AIDS patients.

\section{ACKNOWLEDGEMENTS}

We acknowledge the involvement of Melat Seid and Nejimu Kasim in data collection. We thank health professionals working in Arba Minch Hospital for their contribution during data collection. We are grateful to ethical review board of Arba Minch University for giving ethical clearance. Our regards also go to the study subjects for giving consent to participate in the study.

\section{REFERENCES}

1. World Health Organization. Global AIDS update. UNAIDS 2016. Available at http://www.unaids.org/sites/default/files/med

DOI: http://dx.doi.org/10.4314/ejhs.v28i2.6 
ia_asset/global-AIDS-update-

2016_en.pdfaccess date 12 July, 2017.

2. Basak S, Bose S, Mallick SK, Ghosh AK. Intestinal parasitic infections in HIV seropositive patients-A study. J Clin Diagn Res. 2010;4: 2433-7.

3. Gupta S, Narang S, Nunavath V, Singh S. Chronic diarrhoea in HIV patients: prevalence of coccidian parasites. Indian $J$ Med Microbiol. 2008 ;26(2):172.

4. Pollok RC, Farthing MJ. Enteric viruses in HIV-related diarrhoea. Molecular medicine today. 2000; 6(12):483-7.

5. Akinbo FO, Okaka CE, Machado RL, Omoregie R, Onunu AN. Cryptosporidiosis among HIV-infected patients with diarrhea in Edo State, Midwestern Nigeria. Malaysian J Microbiol. 2010; 6:99-101.

6. Kato M, Granich R, Bui DD,et al. The potential impact of expanding antiretroviral therapy and combination prevention in Vietnam: towards elimination of HIV transmission. JAIDS. 2013;63(5):e142-9.

7. Akinbo FO, Okaka CE, Machado RL, Omoregie R, Onunu AN. Cryptosporidiosis among HIV-infected patients with diarrhea in Edo State, Midwestern Nigeria. Malaysian J Microbiol. 2010; 6:99-101.

8. Curry A, Turner AJ, Lucas S. Opportunistic protozoan infections in human immunodeficiency virus disease: review highlighting diagnostic and therapeutic aspects. London: Middlesex School Printing Press, 1990. 3.

9. Goodgame RW. Understanding intestinal spore forming protozoa: Crypto- sporidia, Microsporidia, Isospora, and Cyclospora. Ann Intern Med 1996;124: 429-41.

10. Aksoy U, Tuncay S.Short communication: investigation of intestinal coccidia in patients with diarrhea. Mikrobiyolojibulteni. 2007;41 (1):127-31.

11. Fekadu S, Taye K, Teshome W, Asnake S. Prevalence of parasitic infections in HIVpositive patients in southern Ethiopia: A cross-sectional study. $J$ InfecDevel Count.2013;7(11):868-72.
12. Garcia LS. Diagnostic medical parasitology. American Society for Microbiology Press; 2006.

13. Mathers CD, Loncar D. Projections of global mortality and burden of disease from 2002 to 2030. Plos med. 2006 ;3(11):e442.

14. Srirangaraj S, Venkatesh D. Opportunistic infections in relation to antiretroviral status among AIDS patients from South India. Indian J Med Microbiol. 2011; 29: 395-400.

15. Faye B, Tine RC, Ndiaye JL,et al. Impact of intestinal parasites on intensity of HIV infection in senegal. $J$ AntivirAntiretrovir. 2010;1:11-12.

16. Getaneh A, Medhin G, Shimelis T. Cryptosporidium and Strongyloides stercoralis infections among people with and without HIV infection and efficiency of diagnostic methods for Strongyloidesin Yirgalem Hospital, southern Ethiopia. $B M C$ research notes. 2010;3(1):90.

17. Adamu H, Petros B. Intestinal protozoan infections among HIV positive persons with and without Antiretroviral Treatment (ART) in selected ART centers in Adama, Afar and Dire-Dawa, Ethiopia. Ethiop $J$ Health Dev. 2009;23(2):133-140.

18. Kumie A, Ali A. An overview of environmental health status in Ethiopia with particular emphasis to its organization, drinking water and sanitation: a literature survey. Ethiop $J$ Health Develop. 2005;19(2):89.

19. Central Statistical Agency 2007, Ethiopia.

20. ZeynudinA, Hemalatha K, Kannan S. Prevalence of opportunistic intestinal parasitic infection among HIV infected patients who are taking antiretroviral treatment at Jimma Health Center, Jimma, Ethiopia. European review for medical and pharmacological sciences. 2013;17:513-6.

21. Utzinger J, Rinaldi L, Lohourignon LK,et al. A new sensitive technique for the diagnosis of hookworm infections in humans. Transactions of the Royal Society of Tropical Medicine and Hygiene. 2008 ;102(1):84-90.

22. Henriksen SA, Pohlenz JF. Staining of cryptosporidia by a modified Ziehl-Neelsen

DOI: http://dx.doi.org/10.4314/ejhs.v28i2.6 
technique. ActaVeterinariaScandinavica. 1980; 22(3-4):594-6.

23. Kulkarni SV, Kairon R, Sane SS, et al. Opportunistic parasitic infections in HIV/AIDS patients presenting with diarrhoea by the level of immunesuppression. Indian $J$ Med Res. 2009; 130(1):63.

24. Wiwanitkit V. Intestinal parasitic infection in Thai HIV-infected patients with. Different immunity status. BMC Gastroenterol. 2012; 1: 3 .

25. Tarimo DS, Killewo JZ, Minjas JN, Msamanga GI. Prevalence of intestinal parasites in patients with enteropathic AIDS in North-Eastern Tanzania. E Afr Med J. 1996; 73: 397-399.

26. Sangaré I, Bamba S, Cissé M,et al. Prevalence of intestinal opportunistic parasite infections in the University hospital of Bobo-Dioulasso, Burkina Faso. Inf dis pov. 2015;4(1):1-6.

27. Tadesse A, Kassu A. Intestinal parasite isolates in AIDS patients with chronic diarrhoea in Gondar Teaching Hospital, North West Ethiopia. Ethiop Med J. 2005; 43: 93-96.

28. Adamu H, Endeshaw T, Teka T, Kifle A, Petros B. The prevalence of intestinal parasites in paediatricdiarrhoeal and nondiarrhoeal patients in Addis Ababa hospitals, with special emphasis on opportunistic parasitic infections and with insight into the demographic and socio-economic factors. Ethiop J Health Dev. 2006; 20(1):39-46.

29. Mohamoud AF. Strongyloidiasis. Clin Infect Dis. 1996; 23:949-953.
30. Awole M, Gebre-Selassie S, Kassa T, Kibru G. Prevalence of intestinal parasites in HIV infected adult patients in South Western Ethiopia. Ethiop J Health Dev .2011; 17: 7178.

31. Wegayehu T, Adamu H, Petros B. Prevalence of Giardia duodenalis and Cryptosporidium species infections among children and cattle in North Shewa Zone, Ethiopia.BMC Infect Dis2013; 13(1):419.

32. Teklemariam Z, Abate D, Mitiku H, Dessie Y. Prevalence of intestinal parasitic infection among HIV positive persons who are naive and on antiretroviral treatment in HiwotFana Specialized University Hospital, Eastern Ethiopia. ISRN AIDS. 2013; 11:324-329.

33. Assefa S, Erko B, Medhin G, Assefa Z, Shimelis T. Intestinal parasitic infections in relation to HIV/AIDS status, diarrhea and CD4 T-cell count. 2009 BMC Infect Dis9: 155.

34. Lim YAL, Rohela M, Sim BL, Jamaiah I, Nurbayah M. Prevalence of cryptosporidiosis in HIV-infected patients in Kajang Hospital, Selangor. Southeast Asian $J$ Trop Med Public Health 2005; 36: 30-33.

35. Nissapatorn V, Lee C, Quek KF, KhairulAnuar A. AIDS-related opportunistic infections in Hospital Kuala Lumpur. Jpn $J$ Infect Dis 2003; 56:187-192.

36. Abossie A, Petros, B. Deworming and the immune status of HIV positive preantiretroviral therapy individuals in Arba Minch, Chencha and Gidole hospitals, Southern Ethiopia. BMC Res Notes 2015;8:483. 